\title{
Crambe Cake to Meloidogyne javanica Control in Lettuce
}

\author{
Júlio César Antunes Ferreira ${ }^{1}$, Olívia Diulen Costa Brito $^{2}$, Paula Juliana Grotto Débia ${ }^{1}$, Beatriz de Almeida Silva ${ }^{3}$, \\ Guilherme Tarini ${ }^{3} \&$ Claudia R. Dias-Arieira ${ }^{1}$ \\ ${ }^{1}$ Agricultural Sciences Post-Graduate, State University of Maringa, Umuarama Regional Campus, Umuarama, \\ PR, Brazil \\ ${ }^{2}$ Agronomy Post-Graduate, State University of Maringa, Maringa, PR, Brazil \\ ${ }^{3}$ Department of Agriculture, State University of Maringa, Umuarama Regional Campus, Umuarama, PR, Brazil \\ Correspondence: Claudia R. Dias-Arieira, Universidade Estadual de Maringá/PGA, Avenida Colombo, n. \\ 5790-Bloco J45, $2^{\circ}$ Piso, 87020-900, Maringá, Paraná, Brazil. Tel: 55-44-999-044-320. E-mail: \\ crdarieira@uem.br
}

Received: January 15, 2018

Accepted: March 2, $2018 \quad$ Online Published: September 15, 2018

doi:10.5539/jas.v10n10p163

URL: https://doi.org/10.5539/jas.v10n10p163

\begin{abstract}
Crambe is an oilseed, which pressing for oil extraction results in the waste called crambe cake. The aforementioned waste may present potential to control nematodes, since it derives from brassica species. The aim of the current study is to assess the best crambe cake application to control Meloidogyne javanica in lettuce plants. Five experiments were carried out in a greenhouse by adopting different crambe cake application procedures; each experiment comprised five treatments ( 0 (control), 5; 10;15; $20 \mathrm{~g}$ crambe cake per $1 \mathrm{~L}$ soil). Lettuce seedlings were cultivated in soil treated with crambe cake, and inoculated with 5,000 nematode eggs and occasional juveniles (J2). Nematological and vegetative parameters were assessed 45 days after inoculation. Nematode reduction was observed in the experiment that applied doses close to $15 \mathrm{~g}$ crambe cake to the soil surface; nematode control recorded 83 and $68 \%$ for eggs and $\mathrm{J} 2$ total and per root gram, respectively. The same parameters showed up to 82 and $93 \%$ reduction when the cake was incorporated to the first $8 \mathrm{~cm}$ deep into the soil. The number of eggs and $\mathrm{J} 2$ per root system reduced by $93 \%$ when the cake was incorporated to the total soil volume. Overall, the crambe cake did not increase plant development; in some cases, phytotoxicity was observed at the highest doses.
\end{abstract}

Keywords: organic fertilization, Brassicaceae, organic matter, root-knot nematodes, Crambe abyssinica

\section{Introduction}

Plant parasitic nematodes stand out among the most destructive pathogens found in agriculture, since they lead to significant annual losses in susceptible plants. Meloidogyne javanica (Treub) Chitwood and M. incognita (Kofoid \& White) Chitwood are reported as the nematodes most affecting lettuce crops, mainly in tropical and subtropical countries, where the continuous lettuce cultivation in certain areas leads to significant nematode population increase due to successive pathogen cycles (Pinheiro et al., 2013).

Root-knot nematodes are sedentary endoparasites; females have piriform body and produce, on average, 500 eggs per life cycle, which, under favorable conditions, is completed in four weeks. During the parasitism process, female nematodes induce specific sites for feeding, called giant cells, which present high cellular hypertrophy and hyperplasia (Pinheiro et al., 2013) and lead to the emergence of root nodes, called galls.

Managing these parasites is a complex task due to the small number of cultivars presenting high resistance levels (Fiorini et al., 2007; Dias-Arieira et al., 2012). Crop rotation using non-host or antagonist plants is recommended as management practice (Moraes et al., 2006; Santana et al., 2012); however, producers who intensively use cultivation areas show low acceptability to such practice.

Thus, adding organic matter to the soil is one of the most efficient methods for the sustainable control of nematodes affecting vegetables; different organic wastes showed nematode management potential (Lopes et al., 2009; Nazareno et al., 2010; Roldi et al., 2013; Dias-Arieira et al., 2015). The organic matter addition also presents other benefits such as natural enemy population increase and improvements in the physical and chemical properties of the soil, including base saturation, porosity and water conductivity, which allow plants to 
develop better, as well as to become more resistant to these pathogens (McSorley \& Gallaher, 1995; Oka, 2010). Wastes from animal husbandry and agro-industrial processes stand out among the investigated organic matters. Cakes derived from oilseed pressing for vegetable oil or biodiesel production purposes stand out among agro-industrial wastes. It is worth highlighting the filter cake, which is generated in alcohol production plants, as well as the castor bean cake, which derives from the pressing of grains for biodiesel production purposes; both cake types proved to be effective in nematode management studies (Albuquerque et al., 2002; Lopes et al., 2009; Roldi et al., 2013).

Crambe (Crambe abyssinica Hochst) is another crop whose cake presents nematode control potential (Dias-Arieira et al., 2015; Tavares-Silva et al., 2015). The species is an oleaginous brassica, which presents oil conversion efficiency; the crambe oil is characterized by its high erucic acid content - a long-chain fatty acid used to make chemical products (Erikson \& Bassin, 1990; Pitol et al., 2010). Similar to other brassica species, crambe is characterized by the production of glycosinolates (Souza et al., 2009; Pitol et al., 2010) - a chemical molecule that is precursor of compounds such as isothiocyanates, cyanotenes and nitriles, which are characteristically toxic and present nematicidal activity (Mayton et al., 1996; Potter et al., 1998; Zasada \& Ferris, 2004).

Although crambe cake shows nematode control potential, it may also present phytotoxic effects (Tavares-Silva et al., 2015). In addition, there is lack of information about efficient doses able to help managing these pathogens. Therefore, the aim of the current study was to assess different crambe cake application forms and doses to control M. javanica in lettuce plants.

\section{Methods}

The experiments were conducted in a greenhouse located at the geographic coordinates $23^{\circ} 47^{\prime} 28.46^{\prime \prime} \mathrm{S}$ and $53^{\circ} 15^{\prime} 23.46^{\prime \prime} \mathrm{W}$, altitude 430 meters; they followed a completely randomized design, with five treatments $(0$ (control), 5; 10;15; $20 \mathrm{~g}$ crambe cake/L soil) and five replications. Three experiments were conducted separately; they differed from each other according to the way the cake was applied, namely: superficially, incorporated to the first $8 \mathrm{~cm}$ deep into the soil, or incorporated to the total soil volume. The experiments with applied crambe cake applied superficially and incorporated to the first $8 \mathrm{~cm}$ were conducted in two different environments: greenhouse with plastic cover and 50\% shading screen (Experiment 1) and greenhouse with plastic cover and $75 \%$ shading screen (Experiment 2); the last experiment, crambe cake incorporated to the total soil volume, was conducted in a greenhouse with plastic cover and 50\% shading screen, only. The experiments were carried out between January and April 2017.

Lettuce seedlings cv. Vera were initially produced in polyethylene trays containing BioPlant ${ }^{\circledR}$ commercial substrate. Plants showing the first fully-expanded pair of leaves were transplanted to pots containing $1 \mathrm{~L}$ of soil:sand (2:1) mixture, which was previously autoclaved at $120^{\circ} \mathrm{C}$ for two hours; the soil was characterized as dystrophic Red Latosol.

The crambe cake was applied to the substrate (mixture), on the transplantation day, at the previously mentioned doses and treatment types. A cake sample was subjected to laboratory chemical analysis; results showed 43.40 $\mathrm{g} / \mathrm{kg}$, nitrogen, $5.83 \mathrm{~g} / \mathrm{kg}$ phosphorus, $1.32 \mathrm{~g} / \mathrm{kg}$ potassium, $0.33 \mathrm{~g} / \mathrm{kg}$ calcium, $0.08 \mathrm{~g} / \mathrm{kg}$ magnesium, $8.43 \mathrm{~g} / \mathrm{kg}$ sulfur, $23.75 \mathrm{~g} / \mathrm{kg}$ iron, $3.60 \mathrm{~g} / \mathrm{kg}$ manganese, $0.88 \mathrm{~g} / \mathrm{kg}$ copper, $4.42 \mathrm{~g} / \mathrm{kg}$ zinc, $3.67 \mathrm{~g} / \mathrm{kg}$ boron, $54.37 \%$ organic carbon and $93.51 \%$ organic matter.

Each plant was inoculated with 5,000 M. javanica eggs and eventual second-stage juveniles (J2) three days after transplantation. The herein used inoculum was obtained from a pure nematode population kept in tomato roots (cv. Santa Clara) and it was extracted according to the methodology by Hussey and Barker (1973), adapted by Boneti and Ferraz (1981). The suspension was calibrated for 2,500 eggs and eventual $\mathrm{J} 2 / \mathrm{ml}$, using a nematode count slide (Peters' slide) under light microscope. The inoculum was deposited in two equidistant holes in the soil around the root crown.

Plants were collected 45 days after inoculation; shoots and roots were separated. The root system was carefully washed and placed on absorbent paper to remove water excess; next, the root fresh weight was measured. Subsequently, nematodes were extracted according to the previously mentioned methodology. Finally, the number of eggs and J2 was assessed in Peters' slide, under light microscope; the recorded value was divided by the root weight in order to find the number of eggs and $\mathrm{J} 2$ per root gram. The shoot fresh and dry weights were assessed; shoot dry weight was recorded after the shoot was dried in a forced air circulation oven $\left(65^{\circ} \mathrm{C}\right)$ until it reached constant weight. 
Data were subjected to analysis of variance, at $5 \%$ probability; in case of significance, doses were assessed through regression analysis using the SISVAR statistical software (Ferreira, 2011).

\section{Results}

Both experiments wherein the crambe cake was superficially applied to the soil showed positive nematode control - the maximum reduction in the total number of eggs and J2 was recorded at doses close to $15 \mathrm{~g}$ (Experiment $1=15.37 \mathrm{~g}$; and Experiment $2=14.15 \mathrm{~g}$ ) and showed nematode reduction higher than 83\% (Figure 1A). The total reduction of eggs and J2 directly reflected in the number of eggs and $\mathrm{J} 2$ per gram of root; the maximum reduction (68\% in comparison to the control) was recorded at the dose $17.68 \mathrm{~g}$ in Experiment 1, whereas in Experiment 2, it was directly proportional to the applied dose increase (Figure 1B).
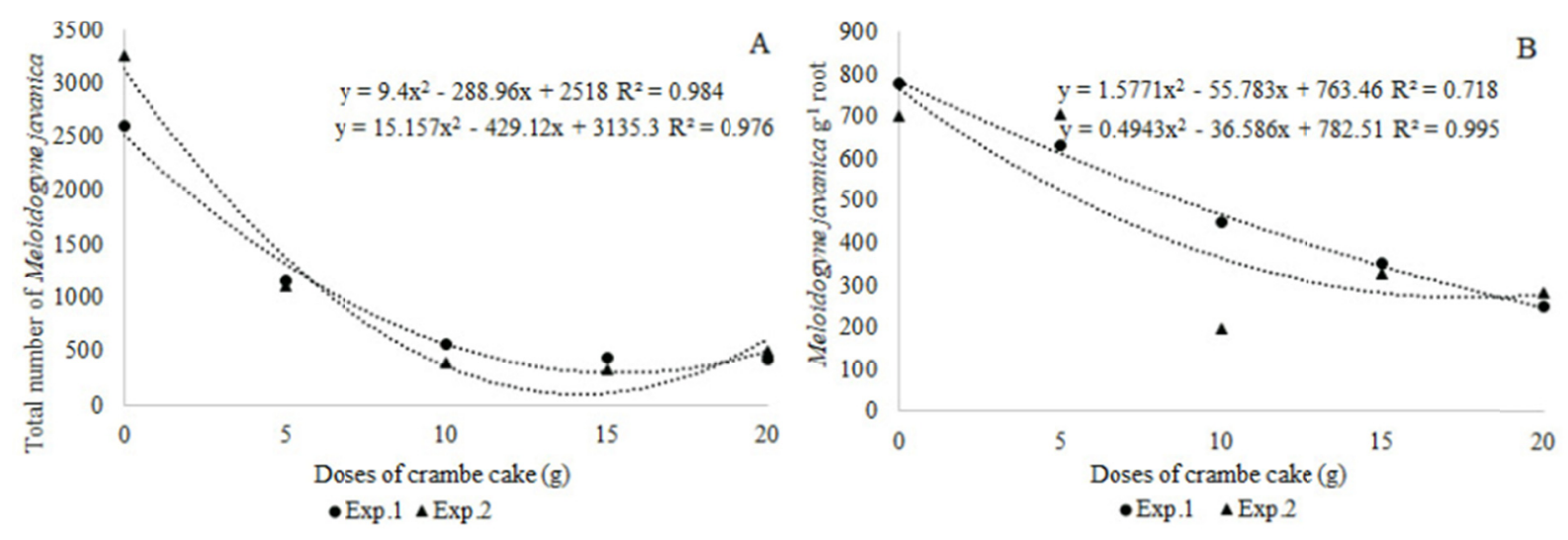

Figure 1. Total number of Meloidogyne javanica eggs and J2 (second-stage juveniles) (A), and total number of Meloidogyne javanica eggs and J2 per root gram (B) in the root system of lettuce plants treated with increasing crambe cake doses superficially applied to the soil. Experiment 1: greenhouse subjected to $50 \%$ shading.

Experiment 2: greenhouse subjected to $75 \%$ shading

The dose $20 \mathrm{~g}$ caused phytotoxicity and plant death when the cake was incorporated to the first $8 \mathrm{~cm}$ deep into the soil. However, the other doses promoted significant reduction in the number of eggs and $\mathrm{J} 2$ in both experiments. The maximum reduction in Experiment 1 was recorded at the dose $15 \mathrm{~g}$, whereas the best results were observed in Experiment 2 when the crambe cake was applied at the dose $12 \mathrm{~g}$ (Figure 2A); reductions ranged from 78 to $82 \%$. The analysis of variance showed significant reduction in number of nematodes per gram of root in Experiment 2, only; the maximum reduction (93\%) was recorded when $7.6 \mathrm{~g}$ crambe cake was applied per pot (Figure 2B).
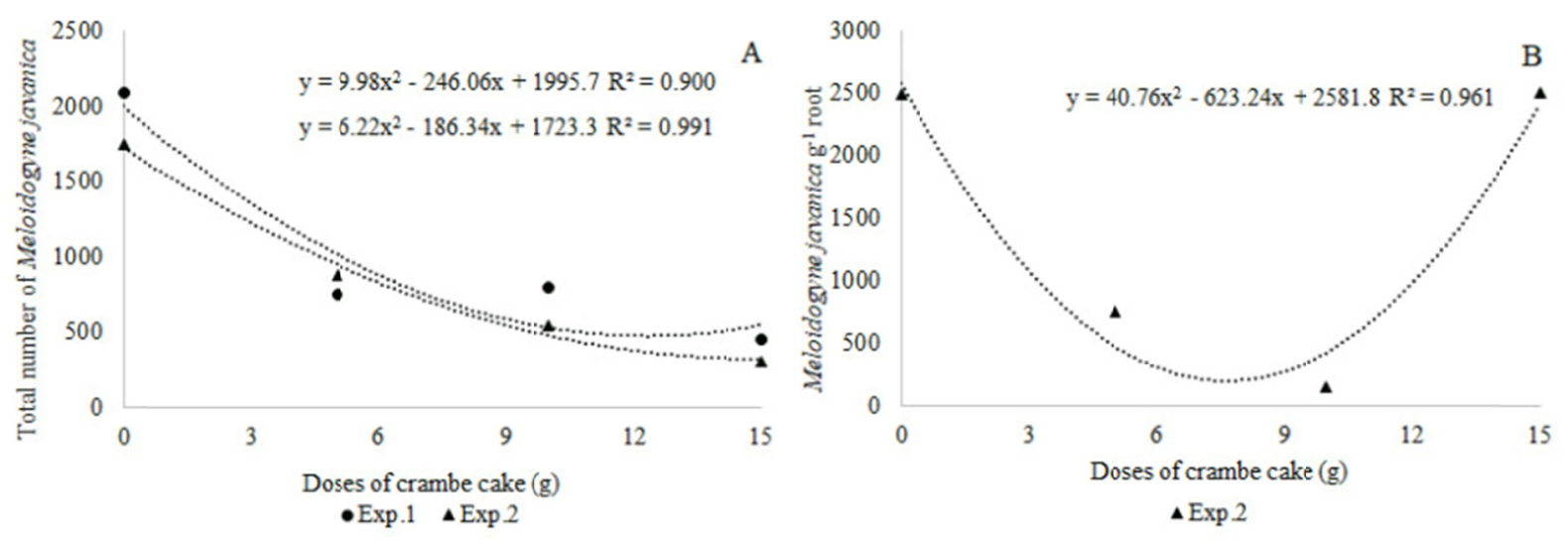

Figure 2. Total number of Meloidogyne javanica eggs and J2 (second-stage juveniles) (A), and total number of Meloidogyne javanica eggs and J2 per root gram (B) in the root system of lettuce plants treated with increasing crambe cake doses incorporated to the first $8 \mathrm{~cm}$ deep into the soil. Experiment 1: greenhouse subjected to $50 \%$ shading. Experiment 2: greenhouse subjected to $75 \%$ shading 
The application of $20 \mathrm{~g}$ crambe cake to the total soil volume also led to plant death, fact that made it impossible assessing these plants. The other doses allowed reducing the total number of eggs and the number of eggs per root gram. The application of $12 \mathrm{~g}$ crambe cake enabled maximum reduction in the total number of eggs and $\mathrm{J} 2$ in the roots (93\%) (Figure 3A), as well as in the number of eggs and J2 per root gram (Figure 3B).
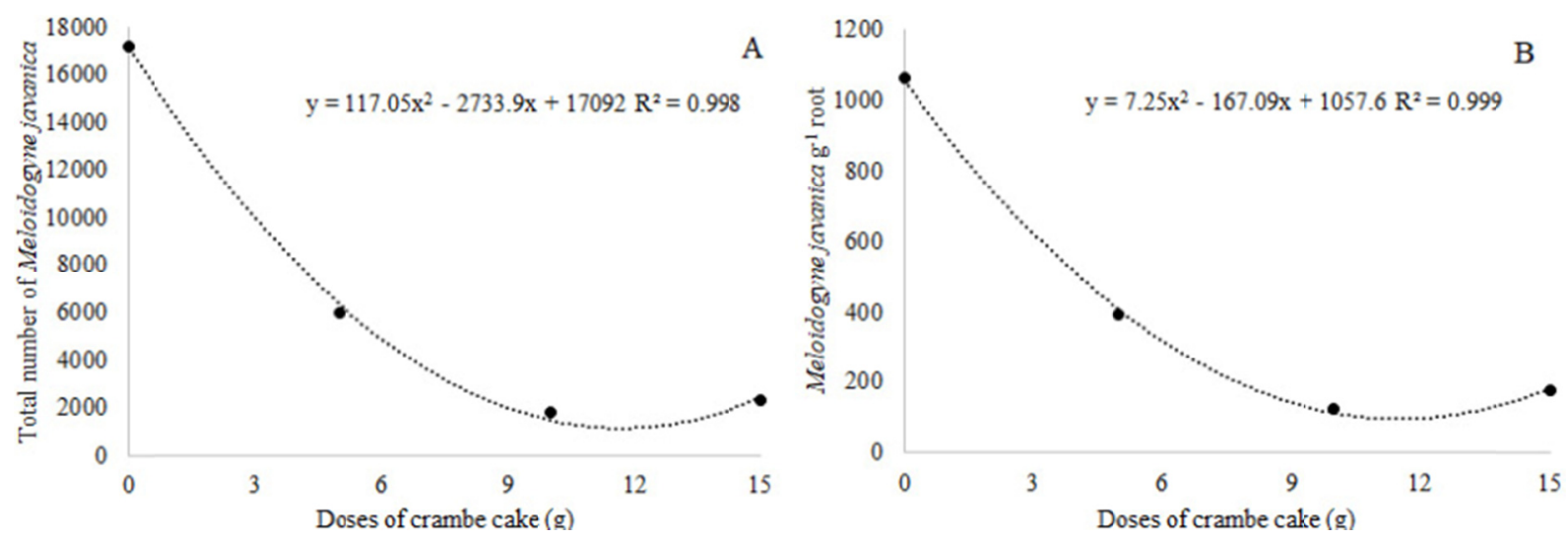

Figure 3. Total number of Meloidogyne javanica eggs and J2 (second-stage juveniles) (A), and total number of Meloidogyne javanica eggs and $\mathrm{J} 2$ per root gram (B) in the root system of lettuce plants treated with increasing crambe cake doses incorporated to $1 \mathrm{~L}$ soil. Greenhouse subjected to $50 \%$ shading

The crambe cake negatively affected lettuce development when it was superficially applied to the soil. There was shoot fresh weight reduction in Experiment 2; it showed minimal development when $13.5 \mathrm{~g}$ crambe cake was applied to the soil (Figure 4A). There was shoot dry weight reduction in both experiments; the lowest means were recorded when the cake was applied at doses ranging from 11.5 to $12.2 \mathrm{~g}$ (Figure 4B). There was root weight reduction in both experiments; minimum weight was recorded when the cake was applied at doses ranging from 13.0 to $14.5 \mathrm{~g}$ (Figure 4C).
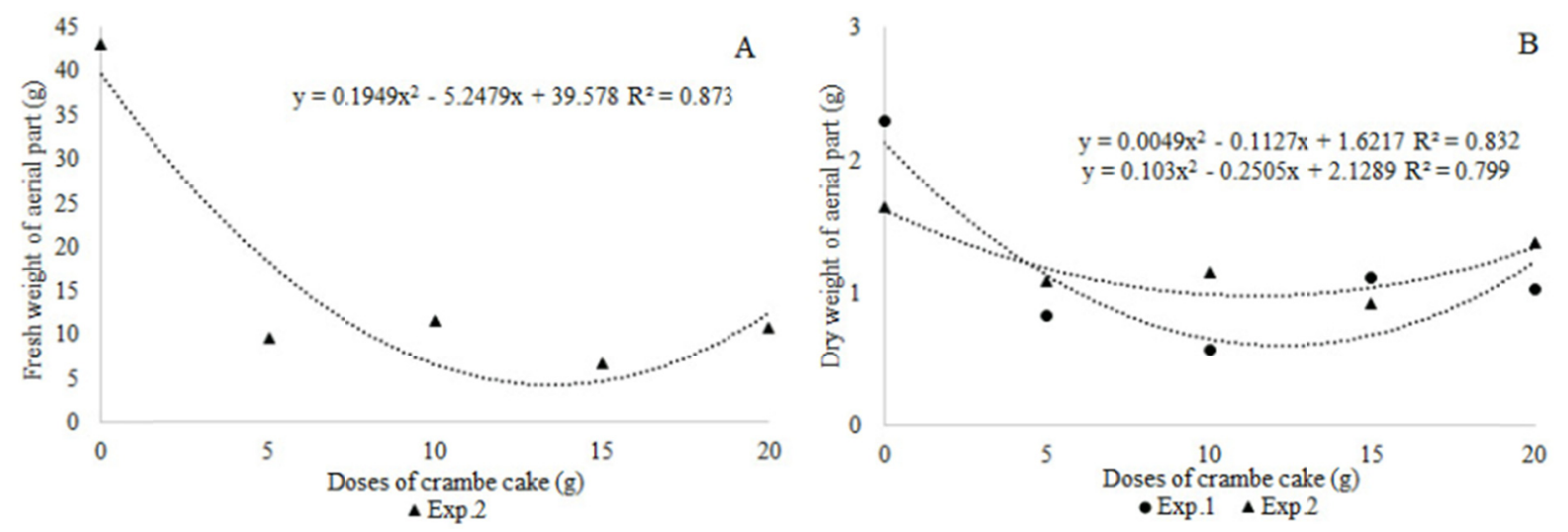


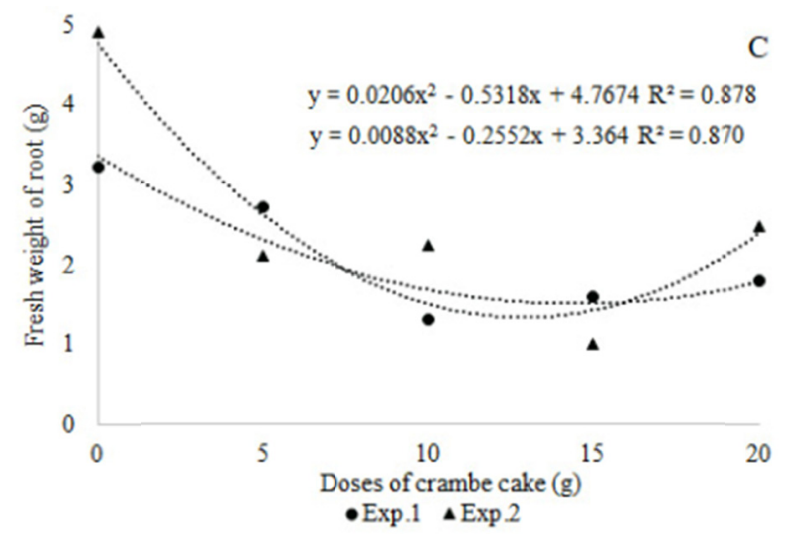

Figure 4. Shoot fresh (A) and dry (B) weight and root fresh weight (C) of lettuce plants treated with increasing crambe cake doses superficially applied to the soil in order to control Meloidogyne javanica. Experiment 1: greenhouse subjected to $50 \%$ shading. Experiment 2: greenhouse subjected to $75 \%$ shading

The root weight was positively affected when the cake was incorporated to the first $8 \mathrm{~cm}$ into the soil in Experiment 2; there was root weight increase at the dose $7.6 \mathrm{~g}$ (regression equation $\mathrm{y}=-0.0428 \mathrm{x}^{2}+0.6524 \mathrm{x}+$ 0.362 and $\mathrm{R}^{2}=59.2 \%$ ). On the other hand, its incorporation to the total soil volume enabled root system reduction directly proportional to the dose increase (equation $y=-0.3664 x+16.783$ and $R^{2}=97.3 \%$ ). The other vegetative parameters were not affected in these experiments (data not shown).

\section{Discussion}

Results showed that, regardless of the crambe cake application form (superficially, incorporated to the first $8 \mathrm{~cm}$ into the soil or to the total soil volume), the treatments enabled significant nematode population reductions, which were expressed both in the total number of nematodes and in the number of nematodes per root gram. Brassicaceae wastes have been investigated for nematode control purposes and recorded satisfactory results in different studies (Mazzola et al., 2001; Reardon et al., 2013; Dias-Arieira et al., 2015; Tavares-Silva et al., 2015). The nematicidal effect recorded in plants belonging to the aforementioned family is related to the plant waste decomposition process, in which glycosinolates are made available to the soil and form bioactive compounds such as isothiocyanates, nitriles and epinitriles, when they react to the myrosinase enzyme (Mayton et al., 1996; Eberlein et al., 1998; Potter et al., 1998; Mazzola et al., 2001).

The crambe cake already showed $M$. javanica control in lettuce plants; reductions varied from 96.9 to $98.9 \%$ when $20 \mathrm{~g}$ crambe cake was incorporated to $2 \mathrm{~L}$ soil (v: v) (Dias-Arieira et al., 2015), and also showed positive results for M. javanica and Pratylenchus brachyurus (Godfrey) Filipjev \& Sch. Stekhoven control in soybean crops (Tavares-Silva et al., 2015). Besides the crambe cake, brown mustard (Brassica juncea (L.) Coss), white mustard (Sinapis alba L.) and canola (Brassica napus L.) cakes also recorded nematode suppression effect (Potter et al., 1998; Mazzola et al., 2001; Reardon et al., 2013); soil biofumigation through brassica plants was effective in controlling $M$. javanica and the nematode reproduction showed more than $46 \%$ reduction (Neves et al., 2007).

It is worth highlighting that the high organic matter content in the crambe cake may have contributed to the direct nematode control, as well as indirectly contributed to it through improvements in the chemical, physical and biological features of the soil (Stirling, 1991; McSorley \& Gallaher, 1995; Nico et al., 2004). In addition, the nutrients found in the cake may help increasing plant resistance to pathogens and act on different metabolic pathways in the process of inducing plant resistance to nematode attack (Wang et al., 2003; Walters \& Bringham, 2007; Lenz et al., 2011). Moreover, the high nitrogen concentration in the waste, whose decomposition may release nitrogen compounds, contributes to pathogen population reduction (Rodríguez-Kábana, 1986), since ammonium nitrate may promote cell plasmolysis in nematodes (Spiegel et al., 1987).

With respect to vegetative parameters, the application of crambe cake to the soil surface reduced plant development. However, only the root weight was positively affected when the crambe cake was incorporated to the first $8 \mathrm{~cm}$ deep into the soil, and negatively affected when it was incorporated to the total soil volume, in the other experiments. Thus, it is possible inferring that the crambe cake has toxic effect on lettuce plants. Similar results were recorded when crambe cake application at doses equivalent to 2.5 and $5.0 \%$ of soil volume inhibited soybean seed germination (Tavares-Silva et al., 2015). However, they do not corroborate the results recorded by 
Dias-Arieira et al. (2015), in which the application of $20 \mathrm{~g}$ cake to $2 \mathrm{~L}$ soil increased the shoot fresh weight from 27 to $50 \%$, as well as the root weight from 14 to $23 \%$, in lettuce plants. Some factors - such as the chemical composition of the crambe cake, which was not presented in the study by Dias-Arieira et al. (2015), the plant permanence period (which was 60 days in the aforementioned study), and the soil volume used in the experiment-may have contributed to the difference recorded in these results.

Data suggest that it is necessary taking precautions at the time of use high organic compound doses, because high concentrations of some micronutrients, such as manganese and iron, may favor the cellular redox balance, lead to oxidation, and trigger morphological, biochemical and physiological symptoms, which may lead to decreased plant development (Hell \& Stephan, 2003). In addition, glycosinolates and their derivatives, which may be responsible for nematode control, can have allelopathic effect on plant development (Eberlein et al., 1998). Thus, the incorporation of Brassica napus and crambe wastes reduced germination, delayed seedling emergence, and decreased root length and shoot dry weight in maize (Spiassi et al., 2011). Phytotoxic effect was also observed in tomato plants when 1\% (v: v) crambe cake was applied to $0.33 \mathrm{~L}$ pots (Walker, 1996). However, the aforementioned author reported decrease in this effect after three weeks of compound reaction to the soil; it led to the hypothesis that the initial crambe cake fermentation process may release toxic compounds, as it was observed in other organic matter sources (Sediyama et al., 2008). In addition, the root fresh weight may have had its growth reduced due to high nutrient availability near the root system, which did not stimulate root growth (Raij, 2011).

It is worth emphasizing that the plant shoot was not affected when crambe cake was incorporated to the first 8 $\mathrm{cm}$ deep into the soil or to the total soil volume. In addition, plants grown in commercial areas are often subjected to less stress, because there is no physical constraint to their vegetative development and due to microorganisms able to speed up organic matter decomposition. Thus, complementary studies at field level should be conducted in order to confirm the best crambe cake dose to be applied, as well as to assess the previous fermentation of the material to be used.

In this way, it was concluded that crambe cake reduced the nematode population in the root system, regardless of the application form. The highest doses $(20 \mathrm{~g}$ in $1 \mathrm{~L}$ soil) caused phytotoxicity and compromised the vegetative development of lettuce plants. However, the incorporation of crambe cake to the soil reduced the negative effect on the plant.

\section{References}

Albuquerque, P. H. S., Pedrosa, E. M. R., \& Moura, R. M. (2002). Relação nematoide-hospedeiro em solo infestado por Meloidogyne spp. e tratado com torta de filtro e vinhaça. Nematologia Brasileira, 26, 27-34.

Boneti, J. I. S., \& Ferraz, S. (1981). Modificação do método de Hussey e Barker para extração de ovos de Meloidogyne exigua de raízes de cafeeiro. Fitopatologia Brasileira, 6, 553.

Dias-Arieira, C. R., Cunha, T. P. L., Chiamolera, F. M., Puerari, H. H., Biela, F., \& Santana, S. M. (2012). Reaction of vegetables and aromatic plants to Meloidogyne javanica and M. incognita. Horticultura Brasileira, 30, 322-326. https://doi.org/10.1590/S0102-05362012000200023

Dias-Arieira, C. R., Mattei, D., Puerari, H. H., \& Ribeiro, R. C. F. (2015). Use of organic amendments in the management of root-knot nematode in lettuce. Horticultura Brasileira, 33, 488-492. https://doi.org/ $10.1590 / \mathrm{S} 0102-053620150000400013$

Eberlein, C. V., Morra, M. J., Guttieri, M. J., Brown, P. D., \& Brown, J. (1998). Glucosinolate production by five field-crown Brassica napus cultivars used as green manures. Weed Technology, 12, 712-718.

Erikson, D. B., \& Bassin, P. (1990). Rapeseed and crambe: alternative crops with potential industrial uses. Kansas, Kansas State University.

Ferreira, D. F. (2011). Sisvar: A computer statistical analysis system. Ciência e Agrotecnologia, 35, 1039-1042. https://doi.org/10.1590/S1413-70542011000600001

Fiorini, C. V. A., Gomes, L. A. A., Libânio, R. A., Maluf, W. R., Campos, V. P., Licursi, V., ... Fiorini, I. V. A. (2007). Identification of the $F_{2: 3}$ homozigotic lettuce families resistant to the root-knot nematode. Horticultura Brasileira, 25, 509-513. https://doi.org/10.1590/S0102-05362007000400004

Hell, R., \& Stephan, U. W. (2003). Iron uptake, trafficking and homeostasis in plants. Planta, 216, 541-551. https://doi.org/10.1007/s00425-002-0920-4

Hussey, R. S., \& Barker K. R. (1973). A comparasion of methods of collecting inocula of Meloidogyne spp. including a new technique. Plant Disease Report, 57, 1025-1028. 
Lenz, G., Costa, I. F. D., Arrué, A., Coradini, C., Dressler, V. L., \& Mello, P. A. (2011). Disease severity and green leaf area maintenance depending on the application of micronutrients and fungicides in wheat. Summa Phytopathologica, 37, 119-124. https://doi.org/10.1590/S0100-54052011000200006

Lopes, E. A., Ferraz, S., Dhingra, O. D., Ferreira, P. A., \& Freitas, L. G. (2009). Soil amendment with castor bean oilcake and jack bean seed powder to control Meloidogyne javanica on tomato roots. Nematologia Brasileira, 33, 106-109.

Mayton, H. S., Oliveira, C., Vaughn, S. F., \& Loria, R. (1996). Correlation of fungicidal activity of Brassica species with allyl isothiocyanate production in macerated leaf tissue. Phytopathology, 86, 267-271.

Mazzola, M., Granatstein, D. M., Elfving, D. C., \& Mullinix, K. (2001). Suppression of specific apple root pathogens by Brassica napus seed meal amendment regardless of glucosinolate content. Phytopathology, 91, 673-679. https://doi.org/10.1094/PHYTO.2001.91.7.673

McSorley, R., \& Gallaher, R. N. (1995). Cultural practices improve crop tolerance to nematodes. Nematropica, 25, 53-60.

Moraes, S. R. G., Campos, V. P., Pozza, E. A., Fontanetti, A., Carvalho, G. J., \& Maximiniano, C. (2006). Influence of legumes in the control of nematodes in organic crisphead lettuce and cabbage crops. Fitopatologia Brasileira, 31, 188-191.

Nazareno, G. G., Junqueira, A. M. R., \& Peixoto, J. R. (2010). Effect of organic manure in the control of root knot nematode in greenhouse lettuce. Bioscience Journal, 26, 525-530.

Neves, W. S., Freitas, L. G., Coutinho, M. M., Parreira, D. F., Ferraz, S., \& Costa, M. D. (2007). Biofumigation of soil with species of Brassicaceae for the control of Meloidogyne javanica. Nematologia Brasileira, 31, 195-201.

Nico, A. I., Jiménez-Díaz, R. M., \& Castillo, P. (2004). Control of root-knot nematodes by composted agroindustrial wastes in potting mixtures. Crop Protection, 23, 581-587. https://doi.org/10.1016/j.cropro. 2003.11.005

Oka, Y. (2010). Mechanisms of nematode suppression by organic soil amendments. Applied Soil Ecology, 44, 101-115. https://doi.org/10.1016/j.apsoil.2009.11.003

Pinheiro, J. B., Amaro, G. B., \& Pereira, R. B. (2013). Ocorrência e controle de nematoides em hortaliças folhosas. Circular Técnica 89. Brasília, Embrapa Hortaliças.

Pitol, C., Broch, D. L., \& Roscoe, R. (2010). Tecnologia e produção: crambe 2010. Maracaju, Fundação MS.

Potter, M. J., Davies, K., \& Rathjen, A. J. (1998). Suppressive impact of glucosinolates in Brassica vegetative tissues on root lesion nematode Pratylenchus neglectus. Journal of Chemical Ecology, 24, 67-80.

Raij, B. Van. (2011). Fertilidade do solo e manejo de nutrientes. Brasília, IPNI.

Reardon, C. L., Strauss, S. L., \& Mazzola, M. (2013). Changes in available nitrogen and nematode abundance in response to Brassica seed meal amendment of orchard soil. Soil Biology and Biochemistry, 57, 22-29. https://doi.org/10.1016/j.soilbio.2012.10.011

Rodríguez-Kábana, R. (1986). Organic and inorganic nitrogen amendments to soil as nematode suppressants. Journal of Nematology, 18, 129-135.

Roldi, M., Dias-Arieira, C. R., Severino, J. J., Santana, S. M., Dadazio, T. S., Marini, P. M., \& Mattei, D. (2013). Use of organic amendment to control Meloidogyne incognita on tomatoes. Nematropica, 43, 49-55.

Santana, S. M., Dias-Arieira, C. R., Biela, F., Cunha, T. P. L., Chiamolera, F. M., Roldi, M., \& Abe, V. H. F. (2012). Antagonistic plants in the management of Meloidogyne incognita, in sandy soil of vegetables growing areas. Nematropica, 42, 287-294.

Sediyama, M. A. N., Vidigal, S. M., Pedrosa, M. W., Pinto, C. L. O., \& Salgado, L. T. (2008). Fermentation of pig manure for use as an organic fertilizer. Revista Brasileira de Engenharia Agrícola e Ambiental, 12, 638-644. https://doi.org/10.1590/S1415-43662008000600011

Souza, A. D. V., Fávaro, S. P., Ítavo, L. C. V., \& Roscoe, R. (2009). Chemical characterization of seeds and presscakes of physic nut, radish and crambe. Pesquisa Agropecuária Brasileira, 44, 1328-1335. https://doi.org/10.1590/S0100-204X2009001000017 
Spiassi, A., Fortes, A. M. T., Pereira, D. C., Senem, J., \& Tomazoni, D. (2011). Allelopathy of winter cover straws on the initial maize growth. Semina: Ciências Agrárias, 32, 577-581. https://doi.org/10.5433/1679-0359. $2011 v 32$ n2p577

Spiegel, Y., Chet, I., \& Cohn, E. (1987). Use of chitin for controlling plant-parasitic nematodes. II. Mode of action. Plant and Soil, 98, 337-345.

Stirling, G. R. (1991). Biological control of plant parasitic nematodes: Progress, problems and perspects. Wallingford, CAB International.

Tavares-Silva, C. A., Dias-Arieira, C. R., Rogerio, F., Puerari, H. H., Mattei, D., Silva, T. R. B., \& Ferrarese-Filho, O. (2015). Control of Meloidogyne javanica and Pratylenchus brachyurus with crambe presscake. Nematropica, 45, 130-147.

Walker, J. T. (1996). Crambe and rapeseed meal as soil amendments: Nematicidal potential and phytotoxic effects. Crop Protection, 15, 433-437. https://doi.org/10.1016/0261-2194(96)00001-4

Walters, D. R., \& Bingham, I. J. (2007). Influence of nutrition on disease development caused by fungal pathogens: Implications for plant disease control. Annals of Applied Biology, 151, 307-324. https://oi.org/10.1111/ j.1744-7348.2007.00176.x

Wang, J., Zhang, J., Ma, Y., Wang, L., Yang, L., Shi, S., ... Scnug, E. (2003). Crop resistance to diseases as influenced by sulphur application rates. In L. Ji, G. Chen, E. Schnug, C. Hera, \& S. Haneklaus (Eds.), International World Fertizer Congress (pp. 1285-1296). Shengyang, Liaoning Science and Technology Publishing House.

Zasada, I. A., \& Ferris, H. (2004). Nematode suppression with brassicaceous amendments: Application based upon glucosinolate profiles. Soil Biology and Biochemistry, 36, 1027-1034. https://doi.org/10.1016/j.soilbio. 2003.12.014

\section{Copyrights}

Copyright for this article is retained by the author (s), with first publication rights granted to the journal.

This is an open-access article distributed under the terms and conditions of the Creative Commons Attribution license (http://creativecommons.org/licenses/by/4.0/). 